Instructions for authors, subscriptions and further details:

http://qre.hipatiapress.com

\title{
Challenges in Distance Education During the (Covid-19) Pandemic Period
}

Tamer Sari ${ }^{1} \&$ Funda Nayır ${ }^{2}$

1) Department of Basic Foreign Languages, School of Foreign Languages, Pamukkale University, Turkey

2) Departmant of Educational Sciences, Educational Faculty, Pamukkale University, Turkey

Date of publication: October $28^{\text {th }}, 2020$

Edition period: October 2020 - February 2021

To cite this article: Sari, T., Nayir, F. (2020). Challenges in Distance Education During the (Covid-19) Pandemic Period. Qualitative Research in Education, 9(3), 328-360. doi:10.17583/qre.2020.5872

To link this article: http://dx.doi.org/10.17583/qre.2020. 5872

\section{PLEASE SCROLL DOWN FOR ARTICLE}

The terms and conditions of use are related to the Open Journal System and to Creative Commons Attribution License (CC-BY). 


\section{Challenges in Distance Education During the (Covid- 19) Pandemic Period}

Tamer Sari

Pamukkale University
Funda Nayir

Pamukkale University

(Received: 03 June 2020; Accepted: 26 October 2020; Published: 28 October 2020)

\section{Abstract}

The purpose of this study is to reveal the perceptions of the teachers, administrators, and academics who had to continue distance education during COVID-19 epidemic disease period, about the problems they experienced and the strategies to cope with the challenges. The working group of the current study consists of 65 teachers. The data were collected via an openendedwritten interview. Content analysis was applied for analysis of the data gathered. Various important results regarding the use of distance education were obtained during the pandemic period and yielded significant findings. The first and the most important finding is that theachers have difficulties in internet access and lack of infrastructure, classroom management and human resources. Another challenge that participants reported was about teachers' and students' behaviours. The last theme stated by the participants is the distance education process itself. The findings reveal that the participants determined their strategies to deal with these problems with new arrangements regarding the classroom management, getting help from colleagues, family members and experts and communicating with students and parents. It can be certainly suggested that the participants are not ready for the distance education process and there is a lack of application in this regard; such as technology support and distance education training, and moreover, the participants do not have sufficient knowledge and experience about distance education.

Keywords: Distance education and online learning, media in education, mobile learning, 21st century abilities 


\section{Retos de la Educación a Distancia Durante el Período Pandémico (Covid-19)}

Tamer Sari

Pamukkale University
Funda Nayır

Pamukkale University

(Recibido: 03 de junio de 2020; Aceptado: 26 de octubre de 2020; Publicado: 28 de octubre de 2020)

\section{Resumen}

El propósito de este estudio es revelar las percepciones de los profesores, administradores y académicos que tuvieron que continuar con la educación a distancia durante el período de la enfermedad epidémica COVID-19, acerca de los problemas que experimentaron y las estrategias para hacer frente a los desafíos. El grupo de trabajo del presente estudio está formado por 65 profesores. Los datos se recogieron mediante una entrevista abierta. Se aplicó un análisis de contenido para analizar los datos reunidos. Durante el período de la pandemia se obtuvieron varios resultados importantes en relación con el uso de la educación a distancia, que arrojaron resultados significativos. La primera y más importante conclusión es que los profesores tienen dificultades de acceso a Internet y carecen de infraestructura, gestión de las aulas y recursos humanos. Otro desafío que los participantes informaron se refería al comportamiento de los profesores y los estudiantes. El último tema señalado por los participantes es el proceso de educación a distancia en sí mismo. Las conclusiones revelan que los participantes determinaron sus estrategias para hacer frente a esos problemas con nuevas disposiciones relativas a la gestión del aula, la obtención de ayuda de colegas, familiares y expertos y la comunicación con los estudiantes y los padres. Ciertamente se puede sugerir que los participantes no están preparados para el proceso de educación a distancia y que hay una falta de aplicación a este respecto; por ejemplo, el apoyo tecnológico y la capacitación en educación a distancia, y además, los participantes no tienen suficientes conocimientos y experiencia sobre la educación a distancia.

Palabras clave: Educación a distancia y aprendizaje en línea, medios de comunicación en la educación, aprendizaje móvil, habilidades del siglo XXI 
T

he geographical locations used when defining the theory known as the butterfly effect were used as Brazil and Texas as the first emergence of this metaphor. According to the theory, a butterfly flapping in Brazil can cause a storm in Texas (Dooley, 2009). However, the late 2019, a butterfly flapping its wings in China's Wuhan (Liu et al., 2020) city stormed all over the world. This storm was an outbreak when an unprecedented virus (known as COVID-19) began to spread from person to person. The characteristics required to identify a disease as an epidemic have been identified by the World Health Organization. The 6 phases identified by the World Health Organization specify the type of outbreak and the extent of the danger. To illustrate these phases according to their degrees, the first phase is that viruses that spread from animals to animals have not been reported to cause infection in humans. While the third phase is defined as the temporary transformation of the influenza virus between animal-animal or human-animal to cause illness in humans, the sixth phase is characterized by the outbreak of the human-to-human virus in at least two or more countries in the WHO region. The determination of the sixth phase indicates that a global pandemic has begun (WHO, 2013).

The declaration of pandemics by the world health organization has led many countries to understand the importance of the issue and take more serious measures to struggle with the epidemic. An important method of nonpharmaceutical interventions, which is part of the fight against epidemics, is to apply quarantine and social isolation (Feng et al., 2007). Isolation, one of the requirements of preventing the transmission of epidemics in the community, is the first to ensure that circulation is reduced by the closure of schools. Instructions for closing schools are often coarranged with additional nonpharmaceutical interventions such as quarantine, isolation, prohibition of public meetings, gradual working hours, and orders to use face masks. However, the closure of schools has brought up another vital problem awaiting a solution as part of the fight against the epidemic in terms of planning the during and post-epidemic period.

Critical epidemiological criteria to guide decisions regarding the implementation of non-pharmaceutical interventions, such as closing schools, are an essential step in reducing the impact of the circulating virus (Stern et al., 2009). Temporary closure of schools in unusual situations, such as excessive snow or rain, the risk of a storm earthquake or extreme 
temperatures in the region, are common measures. However, in a time of pandemic virus outbreaks that has not yet been vaccinated and which affects a large part of society and even the world, it is unpredictable when closed schools can start education again. In these unforeseen situations, administrators try to prepare emergency action plans and prepare for possible scenarios in order to make schools ready. One of the best examples of these preparations was the formation of a team within the University of Minnesota School of Public Health in February 2006 (McGuire, 2007). The task of the created team is to create scenarios on how the training can continue in the event of a possible epidemic. The team makes the scenarios realistic by considering the pandemics experienced before. Among the basic concepts of the scenarios were that epidemics were unpredictable; their time is uncertain and it is not clear who will be affected. Among the suggestions they have prepared are the remarkable ones about continuing education: determining which of the lessons are available online and which lessons' materials are not ready, determining the software and hardware needed to continue the lessons online. It is once again stated that distance education is only alternative or complementary to traditional education, not included in these and similar emergency action plans.

The closing of schools in 43 cities in the United States during the Spanish flu epidemic of 1918-19 saved the lives of many Americans (Stern et al., 2009), however, given the technological possibilities of those days, education could only be continued via post in some cities. The infrastructure of today's technology and prevalence offered different opportunities when compared to a century ago. Thanks to the development of technology, the World was able to produce alternatives instead of interrupting education during the covid-19 outbreak. The National Emergency Action Plan has been prepared in Turkey as well as in many countries with the recommendations of the World Health Organization (Turkish Republic Health Ministry, 2019) and measures to be taken in case of a possible outbreak have been determined. Among these measures dated 20.04.2019, while determining the Duties of the Member Institutions and Organizations in the National Coordination Board, one of the duties of the Ministry of National Education is "Taking the necessary decisions for continuing distance education in case of a break in education and training". Unfortunately, these predictions came true, and the whole world suddenly became familiar with the concept of distance education. 


\section{About Distance Education}

Almost all of the education systems in the world try to fight against coronavirus (COVID-19) pandemic and find ways to continue education during the epidemic. Today's OECD data show that 102 countries around the world have closed all schools to stop the spread of the virus, and about 900 million children and young people stay away from school. Schools in certain cities and regions have been closed in 11 other countries, as well as in countries that have completely closed schools. Unfortunately, these numbers are changing day by day in the time of the epidemic (OECD, 2020a). The whole world realized once again that viruses that do not distinguish between social class do not need a passport.

For a growing list of countries that close their schools, OECD is looking for innovative technological solutions to provide quality teaching and learning. For example, the Turkish Ministry of National Education launched distance education through the Educational Information Network (EBA) for all levels of schools. Moreover, considering the disadvantaged students in regions with insufficient technological infrastructure, 6 television channels opened for use in education and increased the education inclusion rate (Ministry of National Education [MoNE], 2020). Furthermore, although it was announced in the CoHE press release ( Council of Higher Education [CoHE], 2020a) on 18 March 2020, the necessary legal arrangements were made for universities to continue their education with distance education, CoHE allows university students to suspend their studies and postpone enrolment 1 April 2020 due to the problems students experienced in accessing distance education courses (CoHE, 2020b). Briefly, extraordinary times call for extraordinary measures and extraordinary disasters can sometimes bring unexpected consequences, and these consequences can make everything better. At the end of this period, which includes completely new forms of education instead of replacing physical schools with digital ones, education may not be the same as before, like many other things. Distance education, which has existed for many years but has been criticized by a large educational community, may be more involved in life.

COVID-19 crisis hits at a time when most of the education systems are not ready for the world of digital learning opportunities, according to the 
latest report from the OECD's International Student Assessment Program (PISA) (OECD, 2020a). According to PISA 2018, on average across OECD countries, $9 \%$ of 15 -year-old students do not even have a quiet place to study in their homes, and also the same percentage can be mentioned for the availability of effective professional resources for teachers to learn how to use the digital devices available (OECD, 2020a). On average among OECD countries, only $50 \%$ of 15 -year-olds are enrolled in schools where an effective online learning support platform is reported to be available. A similar photograph can be obtained from TALIS - The OECD Teaching and Learning International Survey. According to TALIS, only 53\% of teachers allow their students to use ICT frequently or always for projects or classwork (OECD, 2020b).

Contrary to general belief, distance education is not a very new model of education, contrary to general acceptance. The emergence of distance education applications dates back to about 300 years (Clark, 2020). One of the first known applications is weekly lessons delivered to students in the USA via mail. As well as countries such as England, Switzerland and Australia have provided distance education with different tools (mail, radio, television etc.) years ago due to geographically dispersed and sparse population distribution (Burns, 2011). There are some concepts in literature that are similar in definition and are fundamentally different, which are used interchangeably; Open education, online education, virtual education, elearning, m-learning are some of these. It can be said that all these tools are actually different tools of distance education and they differ from each other in terms of the method or system they use. For instance, m-learning is an educational tool used by a mobile phone or tablet using wireless access, elearning uses similar tools but differently it is more convenient for access to learning materials and mutual interaction between participants (Ally, 2006). The advancement of technology has enabled existing knowledge and information sharing platforms to be processed as dematerialization, such as the transformation of printed books into ebooks, the transformation of newspapers and magazines into websites, and the transformation of traditional classrooms into e-learning (Heeks, 2020). Since m-learning provides both online and offline access to education, it can be said that it is more advantageous than e-learning especially in social isolation periods (Dahya, 2016; Korucu \& Alkan, 2011). 
Before offering a distance education course, especially a synchronous video conferencing course, the instructor must access additional resources of the faculty such as instructional design and technological services. Because these courses typically use technologies not found in a traditional classroom, faculty familiarity or discomfort can potentially affect participants' or teacher's perceptions. As pedagogical recommendations for distance education are more different than for traditional classroom instruction, enough time to learn both the technology and pedagogical techniques are recommended in order to increase the classroom experience for both students and lecturers for student learning (Roth et al., 2020). For a proper understanding of the philosophy of the distance education system, an effective Learning Management System (LMS) should be considered just like a school without a building, and it is important to consider each course as a classroom. Detailed recording of student performance such as participation in courses, projects, quizzes and exams in the system through LMS is very advantageous in terms of evaluation of the education (Martin, 2020). Different learning outcomes and processes require the use of appropriate learning activities and contexts (Huang et al., 2020). Therefore, distance education practitioners should find a way to create the most effective blend of technology and pedagogy. It should be noted that culture also has a central role in predicting the effectiveness of a particular distance education practice and pedagogy (Saykili, 2018). The active participation experience should be designed to inform students about the prerequisites of the online course, considering the interests of the students and the content of the course, as well as to familiarize them with the culture of the online community and to eliminate the novelty effect that may occur in the student and increase the participation (Shearer et al., 2020).

Although distance education offers significant opportunities in terms of expanding education opportunities, especially in higher education, in developed and developing countries, there have been failures due to the low quality resulting from the lack of investment in educational institutions and the adoption of traditional methods by teaching staff (Dhanarajan, 2001). If teachers in distance education only do lecture and teach, this is not a guarantee of quality education, but only part of the task. Especially online instructors need to model high-quality teaching skills for students' motivation and success (Burns, 2011). This requirement means that teachers' technology 
knowledge and competencies should be high level, but the number of teachers in this skill and ability is limited. On the other hand, today, all of the students continuing their education in primary, secondary and high schools and most of the university students are better equipped than their teachers teaching the same group in technology literacy. According to the findings of a fairly recent study (Gonzalez, et al, 2020) conducted during the pandemic period, distance education, which allows teachers to evaluate objectively, has also positively affected student success thanks to new learning methodologies. In the 21 st century, this group of students is more adapted to the abstract algorithm in terms of online games, social media and internet usage habits such as YouTuber, vlog etc. and they use technology language as a native (Prensky, 2001). While these students are now defined as digital native in terms of technology, those who develop educational policies, manage education, and prepare and explain course content cannot go beyond being digital immigrants, no matter how much they update themselves. Nonetheless, at least these teachers can train themselves on the skills to teach their students. The teaching competencies of teachers who will teach the students of the 21 st century have been determined within the scope of different competence frameworks. For example, Partnership for 21st Century Skills, (2002) insists that one of the skills of 21st century teachers should be the use of digital technology and communication tools. Saavedra \& Opfer, (2012) defined one of the 21 st century teaching skills as exploit technology to support learning. Besides the teacher, who has the ability to use technological tools, has the opportunity to teach critical skills in an environment familiar to students (Lambert \& Cuper, 2008). Consequently, although it was decided to switch to distance education due to the Covid-19 outbreak, teachers who are not ready for the functioning of distance education and face difficulties seem less willing to distance education (Hilli, 2020).

While in the distance education lessons prepared, the problems students experience is collected under the headings of internet access and hardware (computer, tablet, mobile phone, etc.) lack of interaction with the instructor, response time, and socialization, for educators, Legislation, Infrastructure, Human Resources, Content, and Application are the most emphasized challenges in research (Burns, 2011; Korucu \& Alkan, 2011; Littlefield et 
al., 2019; Ng, 2019; Barari et al., 2020, Adnan \& Anwar, 2020; Andersson, 2008).

\section{Purpose of the Study}

The purpose of this study is to reveal the perceptions of the teachers, administrators, and academics who had to continue distance education during COVID-19 epidemic disease period, about the problems they experienced and the strategies to cope with the challenges in distance education. The subject is up-to-date and important as the corona epidemic is still continuing these days, and the difficulties faced by the participants in distance education are very new. For this purpose, answers to the following questions have been sought:

1- What are the challenges faced by the participants in distance education courses?

2- What are the opinions of the participants about the sources of the difficulties they encountered in distance education courses?

3- What are the strategies of the participants to cope with the difficulties they encounter in distance education courses?

\section{Method}

Case study, one of the qualitative research patterns, was used in the current research. Qualitative research in which the subject is interpreted in its natural environment (Guba \& Lincoln, 1994) is a holistic research approach (Merriam \& Grenier, 2019). In case studies, factors related to the situation are investigated and the focus is on how they affect the situation or how they are affected by the situation (Yıldırım \& Şimşek, 2013). In this study, the distance education applied due to the global epidemic has also been considered as a situation and the experiences of the participants regarding this situation have been tried to be revealed.

\section{Working Group}

The working group of the research consists of 65 participants working in different cities in Turkey. Typical case sampling, one of the purposeful 
sampling methods, was used in the research. In typical cases, which are not unusual and involve situations that are known in society in some way, the aim is to have knowledge of the specified subject or to inform those who do not have sufficient knowledge (Patton, 2014). Typical case sampling is the sampling method to show typical, ordinary, normal or average situations (Baltac1, 2018) or to investigate the effects of a particular application or program (Neuman, 2014). In this study, since distance education is an acceptable situation in the society, it was taken as a typical situation and typical case sampling was used because the effects of this typical situation were examined. Demographic information about the participants of the research is given in Table 1 . 
Table 1

Demographic information about the participants

\begin{tabular}{|c|c|c|c|c|}
\hline Variables & Groups & $\mathbf{N}$ & $\%$ & Total \\
\hline \multirow{2}{*}{ Gender } & Female & 37 & 56.9 & \multirow{2}{*}{65} \\
\hline & Male & 28 & 43.1 & \\
\hline \multirow{3}{*}{ Job titles } & Teacher & 44 & 67.7 & \multirow{3}{*}{65} \\
\hline & Administrator & 7 & 10.8 & \\
\hline & Academician & 14 & 21.5 & \\
\hline \multirow{4}{*}{ School stages } & Primary school & 16 & 14.6 & \multirow{4}{*}{65} \\
\hline & Secondary school & 15 & 23.1 & \\
\hline & High School & 20 & 30.8 & \\
\hline & University & 14 & 21.5 & \\
\hline \multirow{2}{*}{ School Types } & Public & 28 & 43.1 & \multirow{2}{*}{65} \\
\hline & Private & 37 & 56.9 & \\
\hline \multirow{2}{*}{ Educational Status } & Bachelor degree & 45 & 69.2 & \multirow{2}{*}{65} \\
\hline & Postgraduate & 20 & 30.8 & \\
\hline \multirow{3}{*}{ Seniority } & $1-10$ years & 31 & 47.7 & \multirow{3}{*}{65} \\
\hline & $11-20$ years & 24 & 36.9 & \\
\hline & 21 and over years & 10 & 15.4 & \\
\hline Distance Education & Yes & 19 & 29.2 & \multirow{2}{*}{65} \\
\hline Experience & No & 46 & 70.8 & \\
\hline Training for & Yes & 21 & 32.5 & \multirow{2}{*}{65} \\
\hline Distance Education & No & 44 & 67.7 & \\
\hline
\end{tabular}

When the data related to the study group are examined, as shown in Table 1, the demographic data of the study are; 37 of the participants were women, 28 were men and 44 were teachers, 7 were administrators and 14 were academics. 16 of the participants work in primary schools, 15 in secondary 
schools, 20 in high schools and 14 in universities, 28 in public schools and 37 in private schools. 45 of the participants have a bachelor's degree and 20 have a postgraduate degree. Nearly half of participants have a seniority of 110 years, and the seniority of the participants ranges from 1 year to 35 years. While 19 of the participants have experience in distance education, 46 of them have no experience. 21 of the participants attended a training on distance education, but 44 of them did not attend any training.

\section{Data Collection and Tools}

The data of the research were collected via written responses of the participants with the "standardized open-ended interview" developed by the researchers. The standardized open-ended interview consists of a series of pre-prepared and sequenced questions, which are asked to all participants in the same style and order (Patton, 2014). In this approach, while instantaneous attitude and flexibility are limited, asking all participants in a systematic order provides the advantage in terms of minimizing interviewer influence and subjective judgments (Y1ldırım \& Şimşek, 2013). The interview form consists of two parts. In the first part, demographic information about the participants and in the second part, open-ended questions about the views of the participants about distance education are included. The interview form was sent electronically to the participants using "Google Forms" and the opinions of the participants were received in written forms.

\section{Data Analysis}

Content analysis was used in the analysis of the data. Content analysis is an analysis that aims to reach the concepts and themes that can explain the collected data, to gather similar data within the framework of certain concepts and themes and to present them in a way that the reader can understand (Yıldırım \& Şimşek, 2013). In this study, the answers given for each question were first examined and similar statements were combined and coded. The data obtained were coded manually by the researchers. While coding the data, both the conceptual structure of the literature was based and new codes were created according to the answers given. The encoded data is combined and themes are created by identifying common aspects. As at the 
last step, the resulting codes and themes are explained and the findings are interpreted.

\section{Validity and Reliability}

In qualitative research, the validity and reliability of the studies are met with the criteria of internal validity (credibility), external validity (transferability), internal reliability (consistency) and external reliability (verifiability) (Shenton, 2004; Y1ldırım \& Şimşek, 2013). Data collection process, data analysis and interpretation process are given in detail for the internal validity of the research. In addition, the data analysis process was checked by an external researcher. The findings of the research for external validity were interpreted together with the previous research results and similarities and differences were revealed. Direct citations of the participants were included in interpreting the data for the internal reliability of the research. Also, the data were calculated by both researchers, the percentage of agreement was calculated. According to Miles and Huberman, (1994), the percentage of fit must be $70 \%$ or more. In this study, the percentage of agreement was calculated as ,92 and it can be stated that the coding carried out in the research has high reliability. For the external reliability of the research, the Questions were directed to the participants impartially and the answers were received in writing without any intervention. While giving information about the participants, every participant whose names are kept secret is numbered.

\section{Findings}

The opinions of the participants about the problems they faced during the distance education process are given in Table 2. 
Table 2

Opinions of the participants about the challenges

\begin{tabular}{|c|c|c|c|c|}
\hline Question & Theme & Expressions from opinions & $\mathbf{f}$ & $\%$ \\
\hline \multirow{6}{*}{$\begin{array}{l}\text { What are the } \\
\text { challenges } \\
\text { you encounter } \\
\text { in the distance } \\
\text { education } \\
\text { process? }\end{array}$} & $\begin{array}{l}\text { Internet } \\
\text { Access and } \\
\text { Infrastructure } \\
\text { Deficiency }\end{array}$ & $\begin{array}{l}\text { Internet connection-63,31,4,26,61,49, } \\
25,47,5,8,31,10,28,34,22,15,2,62,11,57 \text {, } \\
1,20,27 \\
\text { Infrastructure deficiency-1,59,39,60, } \\
54,41,35,16 \\
\text { Students with no internet access-63, } \\
18,26,19,46 \\
\text { Technical troubles-18,54,58 } \\
\text { Technological deficiency }-29,43,33,10\end{array}$ & 43 & 50 \\
\hline & $\begin{array}{l}\text { Classroom } \\
\text { management }\end{array}$ & $\begin{array}{l}\text { Difficulty of communicate- } 45,51,4 \text {, } \\
21,61,49,55,52,32,60,11,14,6 \\
\text { Student participation- } 59,4,26,46,5,4 \text {, } \\
40,38,31,17,44,48 \\
\text { Failure to follow the students- } \\
50,21,42,32,12,37 \\
\text { Inability to use the course material- } \\
29,57,33\end{array}$ & 34 & 40 \\
\hline & $\begin{array}{l}\text { Human } \\
\text { resources }\end{array}$ & $\begin{array}{l}\text { Inability to use the DE system- } \\
59,30,10,18 \\
\text { Inability to follow the lesson on the } \\
\text { screen-3 }\end{array}$ & 5 & 5.8 \\
\hline & No problem & no difficulty-7,36 & 2 & 2.3 \\
\hline & Other & $\begin{array}{l}\text { Difficulty teaching in the family } \\
\text { environment-53 } \\
\text { Do not know- } 65\end{array}$ & 2 & 2.3 \\
\hline & & Total & 86 & 100 \\
\hline
\end{tabular}

In Table 2, it is seen that 43 opinions stated by the participants are under the theme of internet access and lack of infrastructure. The opinions expressed by the participants under this theme are problems with internet 
connection, lack of infrastructure, inability to reach students who do not have access to the internet, technical difficulties and lack of technology. The following sentences can be given as examples to the opinions of the participants on this theme:

Having audio and video problems due to lack of internet connections (P47)

Insufficient efficiency in courses due to lack of necessary infrastructure (P39)

...Difficulty to reach students without technological material.... (P26)

Technical difficulties and infrastructure problems (P54)

Pc is not in sufficient capacity and has difficulty in running programs (P43)

It was determined that 34 opinions expressed by the participants were under the theme of classroom management. The opinions expressed by the participants under this theme are related to not being able to communicate in the lessons, following the student, using materials and student participation in the lesson. The following sentences can be given as an example to the participants' views on this theme:

Inability to notice emotion and body language, inefficiency of communication. (P55)

Distraction, lack of focus, not being able to attend class effectively....(P5)

Being unable to understand what the student has learned and how to learn because there is no live broadcast, not being able to answer the student's questions instantly. (P21)

not being able to use enough course material....(P29) 
5 opinions stated by the participants were gathered under the theme of human resources. The opinions expressed by the participants under this theme are related to the teacher or student not being able to use the system effectively and to follow the lesson. The following sentences can be given as examples to the opinions of the participants on this theme.

I have a difficulty in writing while I'm working. I don't have a touch screen. (P30)

It is very difficult to follow the lesson on the screen. (P3)

Two participants stated that they did not have any difficulty in this regard. Two of the opinions expressed by the participants were taken under the theme of "other". In this theme, one (P53) of the participants stated that "I have a two-year-old child and it is very difficult to manage this process with him." Another participant (P65) stated that "he did not know the difficulties regarding this process". The opinions of the participants about the source of the challenges they faced during the distance education are given in Table 3. 
Table 3

Participants' views on the source of the challenges

\begin{tabular}{|c|c|c|c|c|}
\hline Question & Theme & Expressions from opinions & $\mathbf{f}$ & $\%$ \\
\hline \multirow{4}{*}{$\begin{array}{l}\text { What are the } \\
\text { sources of the } \\
\text { challenges you } \\
\text { encounter in the } \\
\text { distance } \\
\text { education } \\
\text { process? }\end{array}$} & $\begin{array}{l}\text { Problems } \\
\text { arising due to } \\
\text { deficiency of } \\
\text { technology and } \\
\text { infrastructure }\end{array}$ & $\begin{array}{l}\text { Internet access- } \\
19,53,21,42,26,25,8,1,47 \text {, } \\
\text { Infrastructure deficiency- } \\
2,62,61,58,22,4 \\
\text { Limited infrastructure- } \\
13,33,54,34,2,27 \\
\text { Technical troubles- } \\
15,32,49,39,60,52,14 \\
\text { Lack of support for the LMS } \\
\text { program used-20,21,7 }\end{array}$ & 30 & 47.8 \\
\hline & $\begin{array}{l}\text { Problems } \\
\text { related to the } \\
\text { distance } \\
\text { education } \\
\text { process }\end{array}$ & $\begin{array}{l}\text { Student attitude- } \\
29,51,42,17,12 \\
\text { Individual deficiency-30 } \\
\text { Difficulty to communicate- } \\
32,3,49,55 \\
\text { Unprepared students and } \\
\text { teachers-58,63 } \\
\text { Lack of education on distance } \\
\text { education- } 45,33,46,44,58 \\
\text { Negative attitudes and bias } \\
\text { towards distance education- } \\
\text { 13,28 } \\
\text { No pre-application-31,9,56,59 }\end{array}$ & 12 & 17.6 \\
\hline & Other & $\begin{array}{l}\text { Lack of content- } 38,60,35 \\
\text { No problem-36,50,48 } \\
\text { Not to be done in earnest-10 } \\
\text { Problems caused by the school } \\
\text { or management- } 23,64,10,16\end{array}$ & 10 & 15.9 \\
\hline & & Total & 63 & \\
\hline
\end{tabular}


As seen in Table 3, the participants consider the problems arising from the lack of technology and infrastructure as the source of the problems they encounter in the distance education process. Of the 62 opinions stated by the participants, 30 opinions were included in this theme. The sources of problems stated by the participants under this theme are internet shortage, lack of infrastructure, inadequate infrastructure, technical problems and inadequate service support of the program used. The following sentences can be given as examples to the opinions of the participants on this theme:

I think that the lack of system infrastructure brings many problems related to distance education. Not everyone may have the opportunity to connect to the Internet at the same time. (P61)

..... inadequate technical infrastructure...(P33)

.... Internet access problems differing according to living areas. (P19)

Inadequate service of the company providing the LMS Program. (P20)

I think that the lack of system infrastructure brings many problems related to distance education. Not everyone may be able to connect to the Internet at that time. The person may not be sufficient in technology etc...(P61)

Technological infrastructure problems (P39)

12 of the problem sources stated by the participants included the theme of problems arising from the teacher and the student. The sources of problems stated by the participants under this theme are the students' point of view regarding distance education (perception as a holiday, disregard, etc.), individual deficiency, lack of communication between teacher and student, and also that the teacher and student are not ready for distance education process. The following sentences can be given as examples to the opinions of the participants on this theme: 
Behavioural problems resulting from the understanding that it is time for younger students to meet with friends, to come together and to solve longing....(P29)

I am the cause of some problems. I could have bought a more useful PC. The biggest problem is that we can't have any preparation. (P30)

Lack of face-to-face communication. (P39)

Students and teachers are not ready for distance education. (P58)

11 of the problem sources stated by the participants were under the theme of problems arising from the distance education process. The sources of problems stated by the participants under this theme are the lack of education related to distance education, negative attitudes and prejudices about distance education and no prior application. The following sentences can be given as examples to the opinions of the participants on this theme:

Such a scenario had never been considered before. The demonstration of distance education could be tried. Every teacher, student and parents could be told about the importance of distance education and how to apply. We cannot motivate students and teachers. (P59)

Not to be trained in advance. Even though it is taken, it cannot replace education at school. (P45)

The society considers distance education efficiency is low. (P28)

Finally, 10 of the problem sources stated by the participants were included under the other theme. The sources of problems stated by the participants under this theme are the lack of content, the problems arising from school management and administration, and the distance education being without earnest. 3 participants stated that they did not have any problems during the distance education process. The opinions of the participants regarding the coping strategies related to the challenges they faced during the distance education process are given in Table 4. 
Table 4

Strategies to cope with the challenges

\begin{tabular}{|c|c|c|c|c|}
\hline Question & Theme & Expressions from opinions & $\mathbf{f}$ & $\%$ \\
\hline \multirow{14}{*}{$\begin{array}{l}\text { What are } \\
\text { your } \\
\text { strategies to } \\
\text { cope with the } \\
\text { challenges } \\
\text { you } \\
\text { encountered } \\
\text { in the } \\
\text { distance } \\
\text { education } \\
\text { process? }\end{array}$} & \multirow{3}{*}{$\begin{array}{l}\text { Making } \\
\text { arrangements } \\
\text { for classroom } \\
\text { management }\end{array}$} & Changing syllabus-52,62,47,15 & \multirow[t]{3}{*}{17} & \multirow[t]{3}{*}{25.7} \\
\hline & & $\begin{array}{l}\text { Preparing new activities for the } \\
\text { lesson- } 40,53 \\
\text { Taking attendance- } 24,12 \\
\text { Motivate-51,26,48,3,39 }\end{array}$ & & \\
\hline & & $\begin{array}{l}\text { Using different course } \\
\text { materials-13,11,46,49 }\end{array}$ & & \\
\hline & \multirow{4}{*}{ Getting help } & $\begin{array}{l}\text { Getting help from internet } \\
\text { resources-33,13,54,29,38,10 }\end{array}$ & \multirow[t]{4}{*}{13} & \multirow[t]{4}{*}{19.7} \\
\hline & & $\begin{array}{l}\text { Getting help from colleagues- } \\
33,60,58,21,17\end{array}$ & & \\
\hline & & Getting help from experts-34 & & \\
\hline & & Getting help from the family-33 & & \\
\hline & $\begin{array}{l}\text { Communicating } \\
\text { via different } \\
\text { digital tools }\end{array}$ & $\begin{array}{l}\text { Communicate with parents- } \\
63,54,26,37,57 \\
\text { Communicate with students- } \\
44,26,32,19,45,37\end{array}$ & 11 & 16.7 \\
\hline & $\begin{array}{l}\text { Getting } \\
\text { technological } \\
\text { support }\end{array}$ & $\begin{array}{l}\text { Following new technologies- } \\
57,18,4,59,61 \\
\text { Improving internet speed- } 8,2\end{array}$ & 7 & 10.6 \\
\hline & Individual Effort & Individual effort-30,27,43,16,41 & 5 & 7.6 \\
\hline & \multirow{4}{*}{ Other } & No strategy-5,6,36,42,2,3,64 & \multirow{3}{*}{13} & \multirow{3}{*}{19.7} \\
\hline & & No difficulty-35,50 & & \\
\hline & & Patience-9,22,56,14 & & \\
\hline & & Total & 66 & 100 \\
\hline
\end{tabular}


As can be seen in Table 4, the most commonly used method as strategies to deal with the difficulties that participants face in distance education is to organize classroom management. Out of a total of 66 views stated by respondents, 17 were under this theme. The strategies that the participants use under this theme are to change the course plan, motivate the students, make participation compulsory, prepare activities for the course and use different course material. The following sentences can be given as examples of the opinions of the participants on this theme:

Despite everything, we are together again, I do my best for you to learn your lessons, only your family and teachers think about your future, it shows your self-respect by not having social conversations with your friends during class time. I use motivational sentences like "Let's do our lesson, let's continue. (P51)

By lecturing as short as possible (P62)

Apart from the courses, I created one-on-one question and solution courses with the student. But this method takes a lot of time for the teacher. (P40)

Trying to do what I did during the lesson while at school, it is compulsory to participate in the lesson, thus creating a small classroom environment (P24)

I am researching the platforms that provide the opportunity to teach with distance education effectively and refer to the methods of preparing the lesson plan, content and material according to the best in them. (P13).

13 of the strategies stated by the participants were included in the theme of getting help. Under this theme, the participants stated that they received help from colleagues, experts, internet resources and their families. The following sentences can be given as examples of the opinions of the participants on this theme: 
I tried to train myself by watching videos from internet sources. I have received support from my friends who use distance education in different schools and especially my children studying at secondary and high school. (P33)

I try to use the internet and the pictures about the lessons. (P38)

I try to be in contact with experts to fix the problem. (P34)

Managing the process by working in coordination with teachers in other branches. (P17)

11 of the strategies stated by the participants were under the theme of communicating. Under this theme, participants stated that they communicate more with parents and students. The following sentences can be given as examples of the opinions of the participants on this theme:

Contacting parents to ask for the materials needed by children, and to say that children and parents can reach us directly when they need...(P63)

Having frequent contact with students and parents. (P26)

Trying to interact with the students as much as I can. (P19)

7 of the strategies stated by the participants were under the theme of receiving technological support. Under this theme, participants stated that they are following new technologies and making arrangements for connecting to the internet. The following sentences can be given as examples of the opinions of the participants on this theme:

Researching current solutions and the situation in the rest of the world, following new technologies. (P18)

Trying to improve internet quality. (P8)

Connecting to the Internet late. $(\mathrm{P} 2)$ 
5 of the strategies stated by the participants were included in the theme of individual effort. Under this theme, the participants stated that they were trying to do their best. The following sentences can be given as examples of the opinions of the participants on this theme:

I do my best and constantly impose on the children the seriousness of the work, and the feeling that as if we were in face to face lesson. (P30)

Trying to use the possibilities with maximum benefit. (P41)

Using the facilities as much as I can. (P43)

Finally, 13 of the strategies stated by the participants were included under the other theme. Under this theme, the participants stated that they did not use strategy, had difficulty and tried to manage the process by patience.

\section{Conclusion and Discussion}

In this study, the challenges faced by teachers, administrators and educators during the distance education process, the source of these challenges and their opinions on strategies to cope with these challenges were examined. When the challenges faced by the participants are analysed, it is seen that they mostly have difficulties in internet access and lack of infrastructure, classroom management and human resources. When the literature is examined, it is seen that the difficulties encountered in distance education are addressed under the titles of legislation, infrastructure, internet access, trained human resources, course material, content, and application problems (Dhanarajan, 2001; Andersson, 2008; Burns, 2011; Korucu \& Alkan, 2011; Littlefield et al., 2019; Ng, 2019; Barari et al., 2020; Heeks, 2020). It can be said that the themes emerging in this research are coherent with the themes mentioned in the literature. However, as a remarkable situation, they did not express an opinion on the difficulties they faced regarding the legal dimension of the distance education process. The reason for this may be an extraordinary situation, or that both the Ministry of National Education (MoNE, 2020) and the Council of Higher Education (CoHE, 2020a) 
officially announced the distance education activities provided that they are valid only during the COVID-19 epidemic period

Problems experienced by participants under the theme of internet access and lack of infrastructure are problems that usually arise due to internet access and internet speed. The participants stated that the internet was slow, the connection was cut frequently, they experienced audio and video problems because the connection was not sufficient, and in this case, it caused technical problems. Some participants stated that the internet is not accessible everywhere, especially in rural areas, and in this case, it is insufficient to reach students and there are difficulties because there is not enough technological equipment even if internet access is available.

The difficulty participants experience in the distance education process is about classroom management. It can be accepted that this theme is coherent with the course material and content theme stated in the literature. Content theme specified in the literature can be associated with the information "Providing qualifications that will ensure students; learning, motivation, and participation by knowing that traditional educational materials are not sufficient and/or valid for this platform". Among the problems reported under this theme that emerged in the research were not being able to communicate, difficulty in attracting the student's interest in the lesson, not following the student's development and not being able to use the necessary materials. The participants stated that they could not communicate with the students face to face, so they could not be sure whether the student was listening to the lesson and this made it difficult for the student to participate in the lesson. Another difficulty mentioned under this theme is about using lesson material. Participants stated that they could not use course materials in online courses.

One of the difficulties participants experienced in the distance education process is related to human resources. When the difficulties experienced under this theme are examined, it is seen that the participants are not ready for the distance education process, teachers and students have difficulties in using the system and therefore they have difficulty in following the lesson. These data can be said to be compatible with the digital native theory that Prensky (2001) mentions. When the opinions of the participants regarding the source of the difficulties they experienced were analysed, it was revealed that they first indicated the lack of technology and infrastructure. Participants perceive internet connectivity and infrastructure deficiency as 
the source of their difficulties, however, they state that the program used in the distance education process does not provide sufficient service support.

The participants reported teacher and student behaviours as another source of their difficulties. It has been reported as another problem source that students perceive as a holiday because they are at home during the distance education process. It was thought that the students did not attach the necessary importance to the lesson because of their perceptions and the inability of teachers to use this technology as well as the lack of face-to-face communication between the teacher and the student and the fact that both the teacher and the student were not ready for this process emerged as the main source of problems.

The last theme stated by the participants as the source of the difficulties is the distance education process itself. The fact that there has not been any prior implementation of this process stands out as an important problem, while teachers do not have any training on this issue and therefore negative attitudes and prejudices arising from the process constitute the main source of difficulties. These statements confirmed the information in the literature that teachers who are not ready for the functioning of distance education and face difficulties seem less willing to distance education (Hilli, 2020).

It is observed that the participants making arrangements regarding classroom management in order to deal with the difficulties they faced during the distance education process. They make changes to lesson plans, try to use more relevant attractive materials, use verbal motivation tools for students and prepare extra activities for the lesson. Several participants noted that they use an attendance checklist to make students attend the course. This is an indication that teachers are still trying to solve the process in traditional ways.

Another strategy that participants use to deal with the challenges they face during Distance Education is getting help. It is observed that the participants received help from colleagues, family members and experts who are better at technology in this process. Participants also use the platforms on the internet for help. When some of the participants could not connect to the system, they stated that they were communicating with their students via Skype, etc.

The last strategy used by the participants to deal with the difficulties experienced in the distance education process is to communicate. Participants try to manage the process using different communication tools (e-mail, phone, WhatsApp) with parents and students. 
In addition, although it is an advantage that distance education covers everyone, it creates inequality for students who do not have internet access or have sufficient technical equipment. MEF University provided computer support for students who do not have a computer (MEF, 2020) Ankara Municipality has launched a computer donation campaign for students who do not have a computer (Yavaş, 2020). Some schools across the country gave computers in the school to their students in need. Although these applications solve some of the problems, wider technical solutions should be applied in order to overcome internet infrastructure deficiencies. In the research findings, it can be concluded that the participants are not ready for the distance education process and there is a lack of application; such as technology support and distance education training in this regard. It is clear that the participants do not have sufficient knowledge and experience about distance education, they still need to establish face-to-face training and therefore they have difficulties. It should be also noted that there are various duties for students and parents in the distance education process. Therefore, observing and controlling the students is not only the task of the teacher, this task should be shared between the teacher, the student and the parents. This can contribute to overcome the difficulties by getting rid of the traditional point of view of teachers and developing a perspective on the meaning and philosophy of distance education. It can also be concluded that teachers, administrators and academicians need in-service training related to a distance education process. Participants do not know how to manage the process and create solutions based on their own experiences. When the solution strategies are examined, it is generally seen that the strategies are to get help with the technology and to make appropriate plans for the process. This situation can be interpreted as the participants need support especially in technology. Although the skills that should be gained to educators within the scope of 21st century teaching skills are determined (Partnership for 21st Century Skills, 2002; Saavedra \& Opfer, 2001; Lambert \& Cuper, 2008), it is understood that educators do not have sufficient skills in this regard yet.

The subject is up-to-date and important as the corona epidemic is still continuing these days, and the difficulties faced by the participants in distance education are very new. According to the research findings, the transition to distance education as compulsory in the Covid 19 process caught teachers, administrators and academicians unprepared for distance education 
applications. Nevertheless, technological and system-related difficulties such as lack of infrastructure and internet access have emerged as both the problem and the source of the problem. However, the fact that the participants do not have enough information about the process and are inadequate in using technology causes difficulties in preparing course content and managing the process. Participants produce individual solutions for the problems they face and these solutions are sometimes insufficient.

In order to produce permanent and effective solutions to the problems which teachers experienced during the pandemic period, first of all, the internet and technology infrastructure must be developed. Governments, as well as national and international investors, should take responsibility for solving these problems. Also, Teachers and students, as well as parents, should be included in the training by establishing open access libraries and organizing trainings in terms of course contents. In this epidemic period, which has become a global problem, the education of students is not seen as the duty of only schools and teachers, instead of overloading educators, creating online-access digital learning platforms and supporting education by e-books, v-blocks and social media may reduce the burden of educators. Furthermore, teachers can use teaching methods such as case study, discussions, experimental learning, brainstorming sessions, games, exercises to make lessons more efficient and effective. School administrators can determine new job descriptions for different teacher groups by making a new emergency action plan according to the teaching skills and experiences of teachers. For example, while one group prepares course content and materials, another group can take part in online courses, a third group of teachers can conduct online programs and interviews with students and parents to help students' psychological well-being and social development. Another solution proposal is that providing the sale of tax-free or low-tax digital devices and opening free internet access for students and teachers with the cooperation of governments and private sector can contribute to continuity of education. Finally, providing re-access to online courses for students who do not have regular or permanent internet access, and opening the internet and technology infrastructures of public institutions that may provide access to courses for students who are disadvantaged in terms of access to technology could at least make this difficult process less destructive. 
From this point of view, the findings of the research are important for revising teacher competencies in the 21 st century and revealing deficiencies in order to manage the education process correctly in emergency situations. At this point, it can be thought that the study will contribute to creating an action plan for the global crisis situations.

In this study, first of all, the challenges experienced by teachers, administrators and academicians, sources of challenges and strategies to cope with these difficulties were examined during the distance education process. In future studies, it can contribute to address the problems experienced by the students and to reveal the support needed by the stakeholders involved in the process.

\section{References}

Adnan, M., \& Anwar, K. (2020). Online learning amid the COVID-19 pandemic: Students' perspectives. Journal of Pedagogical Sociology and Psychology, 2(1), 45-51. https://doi.org/10.33902/JPSP. 2020261309

Ally, M. (2006). Foundations of Educational Theory for Online Learning.

Theory and Practice of Online Learning, 1(2), 343-365. https://doi.org/10.1007/978-1-4020-8299-3_8

Andersson, A. (2008). Seven major challenges for e-learning in developing countries: Case study eBIT, Sri Lanka. International Journal of Education and Development using ICT [Online], 4(3). http://ijedict.dec.uwi.edu/viewarticle.php?id=472

Baltacı, A. (2018). Nitel Araştırmalarda örnekleme yöntemleri ve örnek hacmi sorunsalı üzerine kavramsal bir inceleme, Bitlis Eren Üniversitesi Sosyal Bilimler Enstitüsü Dergisi, 7(1), 231-274.

Barari, N., RezaeiZadeh, M., Khorasani, A., \& Alami, F. (2020). Designing and validating educational standards for E-teaching in virtual learning environments (VLEs), based on revised Bloom's taxonomy. Interactive Learning Environments, O(0), 1-13. https://doi.org/10.1080/10494820.2020.1739078 
Burns, M. (2011). Distance Education for Teacher Training: Modes, Models, and Methods. EDC.

http://idd.edc.org/resources/publications/modes-models-and-methods

CDC. (2017). Get your school ready for pandemic flu. CDC.

https://www.cdc.gov/nonpharmaceutical-interventions/pdf/gr-panflu-ed-set.pdf

Clark, J. T. (2020). Distance education. In Clinical Engineering Handbook ( $2^{\circ}$ Ed., Vol. 4), (pp. 410-415). Elsevier Inc.

https://doi.org/10.1080/0158791830040111

CoHE. (2020a). Saraç made a statement on the distance education. CoHE. https://www.yok.gov.tr/en/Sayfalar/news/2020/Sarac-made-astatement-on-the-distance-education.aspx

CoHE. (2020b). English university students allowed to suspend studies and postpone enrollment. CoHE.

https://www.yok.gov.tr/en/Sayfalar/news/2020/University-StudentsAllowed-to-Suspend-Studies-and-Postpone-Enrollment.aspx

Dahya, N. (2016). Education in conflict and crisis: How can technology make a difference? A landscape review. Deutsche Gesellschaft für Internationale Zusammenarbeit (GIZ) GmbH. Results for Education through its Center for Education Innovations in Washington DC.

Dhanarajan, G. (2001) Distance education: Promise, performance and potential, open learning: The Journal of Open, Distance and eLearning, 16:1, 61-68. https://doi.org/10.1080/02680510124465

Dooley, K. J. (2009). The butterfly effect of the "Butterfly effect."

Nonlinear dynamics, Psychology, and Life Sciences, 13(3), 279-288. https://asu.pure.elsevier.com/en/publications/the-butterfly-effect-ofthe-butterfly-effect

Feng, Z., Xu, D., \& Zhao, H. (2007). Epidemiological models with nonexponentially distributed disease stages and applications to disease control. Bulletin of Mathematical Biology, 69(5), 1511-1536. https://doi.org/10.1007/s11538-006-9174-9

González T., de la Rubia, M. A., Hincz, K. P., Comas-López, M., Subirats, L., Fort, S., \& Sacha, G. M. (2020). Influence of COVID-19 confinement on students' performance in higher education. PLoS ONE, 15(10): e0239490. https://doi.org/10.1371/journal.pone.0239490 
Guba, E. G., \& Lincoln, Y. S. (1994). Competing paradigms in qualitative research. In N. K. Denzin \& Y. S. Lincoln (Eds.), Handbook of qualitative research (pp. 105-117). Sage.

Heeks, R., (2020). ICT4D 3.0? Part 1-The components of an emerging "digital-for-development" paradigm. The Electronic Journal of Information Systems in Developing Countries, 86(e12124).

https://doi.org/10.1002/isd2.12124

Hilli, C. (2020). Distance teaching in small rural primary schools: a participatory action research project. Educational Action Research, 28(1), 38-52. https://doi.org/10.1080/09650792.2018.1526695

Huang, R. H., Liu, D. J., Tlili, A., Yang, J. F., Wang, H. H., Zhang, M., Lu, H., Gao, B., Cai, Z., Liu, M., Cheng, W., Cheng, Q., Yin, X., Zhuang, R., Berrada, K., Burgos, D., Chan, C., Chen, N. S., Cui, W., $\mathrm{Hu}, \mathrm{X}$. et al. (2020). Handbook on facilitating flexible learning during educational disruption: The Chinese experience in maintaining undisrupted learning in COVID-19 outbreak. Smart Learning Institute of Beijing Normal University

Korucu, A. T., \& Alkan, A. (2011). Differences between m-learning (mobile learning) and e-learning, basic terminology and usage of $\mathrm{m}$ learning in education. Procedia - Social and Behavioral Sciences, 15, 1925-1930. https://doi.org/10.1016/j.sbspro.2011.04.029

Lambert, J., \& Cuper, P. (2008). Multimedia technologies and familiar spaces: 21 st-century teaching for 21 st-century learners.

Contemporary Issues in Technology and Teacher Education, 8(3), 264- 276. https://citejournal.org/volume-8/issue-3-08/currentpractice/multimedia-technologies-and-familiar-spaces-21 st-centuryteaching-for-21st-century-learners/

Liu, J., Ouyang, L., Guo, P., Wu, H.S., Fu, P., Chen, Y.L., Yang, D., Han, X.Y., Cao, Y.K., Alwalid, O., Tao, J., Peng, S.Y., Shi, H.S., Yang, F., \& Zheng, C.S., (2020). Epidemiological, clinical characteristics and outcome of medical staff infected with COVID-19 in Wuhan, China: A retrospective case series analysis. MedRxyv. https://doi.org/10.1101/2020.03.09.20033118

Littlefield, M. B., Rubinstein, K., \& Laveist, C. B. (2019). Designing for quality: Distance education rubrics for online MSW programs. 
Journal of Teaching in Social Work, 39(4-5), 489-504. https://doi.org/10.1080/08841233.2019.1658691

Martin, A. (2020). How to Optimize Online Learning in the Age of Coronavirus (COVID-19): A 5-Point Guide for Educators.

McGuire, L. (2007). Planning for a pandemic influenza outbreak: Roles for librarian liaisons in emergency delivery of educational programs. Medical Reference Services Quarterly, 26(4), 1-13. https://doi.org/10.1300/J115v26n04_01

MEF Üniversitesi [MEFuniversitesi]. (2020, 11 April)/ [Twitter]. https://twitter.com/MEFuniversitesi

Merriam, S. B., \& Grenier, R. S. (2019). Qualitative research in practice: Examples for discussion and analysis. Jossey-BassPublishers

Miles, M. B., \& Huberman, A.M. (1994). Qualitative data analysis: A sourcebook of new methods. Sage.

MoNE. (2020). Bakan Selçuk, 23 Mart'ta Başlayacak Uzaktan Eğitime Illişkin Detayları Anlattı. https://www.meb.gov.tr/bakan-selcuk-23martta-baslayacak-uzaktan-egitime-iliskin-detaylarianlatti/haber/20554/tr

Neuman, L. W. (2014). Social research methods: Qualitative and quantitative approaches (7th Ed.). Pearson Education Limited.

$\mathrm{Ng}$, C. (2019). Shifting the focus from motivated learners to motivating distributed environments: a review of 40 years of published motivation research in distance education. Distance Education, 40(4), 469-496. https://doi.org/10.1080/01587919.2019.1681892

OECD. (2020a). Education disrupted-education rebuilt: Some insights from PISA on the availability and use of digital tools for learning OECD education and skills today. https://oecdedutoday.com/coronavirus-education-digital-tools-forlearning/

OECD. (2020b). How can teachers and school systems respond to the COVID-19 pandemic? Some lessons from TALIS - OECD education and skills today. https://oecdedutoday.com/how-teachers-schoolsystems-respond-coronavirus-talis/

Partnership for 21st Century Skills. (2002). Learning for the 21st century: A report and MILE guide for. https://eric.ed.gov/?id=ED480035 
Patton, M. Q. (2014). Nitel araştırma ve değerlendirme yöntemleri [Qualitative research \& evaluation methods] (3. Basımdan Çeviri). (M.Bütün, S.B.Demir, Çev. Ed.). Pegem Akademi.

Prensky, M. (2001). Digital natives, Digital immigrants. MCB University Press. https://doi.org/10.1177/1461444818783102

Roth, J. J., Pierce, M., \& Brewer, S. (2020). Performance and satisfaction of resident and distance students in videoconference courses. Journal of Criminal Justice Education, O(0), 1-15. https://doi.org/10.1080/10511253.2020.1726423

Saavedra, A. R., \& Opfer, V. D. (2012). Learning 21st-century skills requires 21st-century teaching. Phi Delta Kappan, 94(2), 8-13. https://doi.org/10.1177/003172171209400203

Saykili, A. (2018). Distance education: Definitions, generations, key concepts and future directions. International Journal of Contemporary Educational Research, 5(1), 2-17. http://search.ebscohost.com/login.aspx?direct=true $\& \mathrm{db}=$ eric $\& \mathrm{AN}=\mathrm{E}$ J1207516\&site=ehost-live \&scope=site

Shearer, R. L., Aldemir, T., Hitchcock, J., Resig, J., Driver, J., \& Kohler, M. (2020). What students want: A vision of a future online learning experience grounded in distance education theory. American Journal of Distance Education, 34(1), 36-52. https://doi.org/10.1080/08923647.2019.1706019

Shenton, A.K. (2004). Strategies for ensuring trustworthiness in a qualitative research projects. Education for Information, 22(2), 6375. https://www.semanticscholar.org/paper/Strategies-for-ensuringtrustworthiness-in-researchShenton/cbe670d35e449ceed731466c316cd273032b28ca

Stern, A. M., Cetron, M. S., \& Markel, H. (2009). Closing the schools: Lessons from the 1918-19 U.S. influenza pandemic: Ninety-one years later, the evidence shows that there are positive and negative ways to do it. Health Affairs, 28(6), w1066-w1078. https://doi.org/10.1377/hlthaff.28.6.w1066

Turkish Republic Health Ministry. (2019). Pandemic influenza national action plan. Ankara. https://www.grip.gov.tr/depo/saglik_calisanlari/ulusal_pandemi_plan i.pdf 
WHO. (2013). Pandemic phase descriptions and actions.

https://www.who.int/influenza/resources/documents/pandemic_phase _descriptions_and_actions.pdf?ua=1

WHO. (2020a). Covid19 coronavirus disease 2019 situation report - 72.

World Health Organization (Vol. 2019).

https://pers.droneemprit.id/covid19/

Yavaş, M. [mansuryavas06 ) (2020, 11 April). Mansur Yavaş Twitter'da:

"Gelin, dayanışmanın eşsiz mutluluğunu birlikte yaşayalım. \#Birli.

[Tweet].

https://twitter.com/mansuryavas06/status/1247126131494584323

Yıldırım, A., \& Şimşek, H. (2013). Sosyal bilimlerde nitel araştırma

yöntemleri. Seçkin Yayıncılık.

Tamer Sari is Lecturer of the Department of Basic Foreign Languages,

School of Foreign Languages, Pamukkale University, Turkey

Funda Nayır is Associate Professor of the Department of Educational Sciences, Educational Faculty, Pamukkale University, Turkey

Contact Address: Tamer Sari, Pamukkale University, School of Foreign Languages, Department of Basic Foreign Languages, Çamlaraltı, Kınıklı Kampüsü, 20070 Pamukkale/Denizli, Turkey. Email: tamersari@pau.edu.tr 